\title{
Correlation between Serum Level of Vitamin D and Severity Degree of Diabetic Foot Ulcer in Patients with Normal Ankle Brachial Index \\ Saleh Harris ${ }^{*}$, Raden Suhartono ${ }^{b}$, Aria Kekalih ${ }^{c}$
}

Introduction: Diabetes mellitus can cause various complications, including diabetic foot ulcers (DFU). Vitamin D levels are known to be correlated with wound healing and insulin resistance.

Method: This cross-sectional study aimed to determine the correlation between the serum level of vitamin D and the severity degree of DFU. Thirty DFU patients with normal anklebrachial index, grouped into degrees according to the Wagner classification, were included in this study. Their serum level of vitamin D was examined using the chemiluminescent immunoassay method. The correlation between these two variables was analyzed.

Results: Patients were 18 males (60\%) and 12 females (40\%) with an average age of 57 years. The average serum level of vitamin D was $10.58 \mathrm{ng} / \mathrm{mL}$. A significant correlation was found between the serum level of vitamin D and the severity of DFU $(r=-0.901, p<0.001)$.

Conclusion: The serum level of vitamin D screening in DFU patients was strongly correlated with the degree of DFU.

Keywords: diabetes mellitus, diabetic foot ulcer, vitamin D, Wagner classification https://doi.org/10.36864/jinasvs.2020.1.009

*Correspondence: doctorsclub96@gmail.com

aM.D., Department of Surgery, Mintohardjo Jakarta Hospital, Jakarta, Indonesia

bM.D., Vascular and Endovascular Division, Department of Surgery, Cipto Mangunkusumo Hospital - Faculty of Medicine, Universitas Indonesia, Jakarta, Indonesia

cM.D., M.T.I., Ph.D., Department of Community Medicine, Faculty of Medicine Universitas Indonesia, Jakarta, Indonesia

\section{INTRODUCTION}

Diabetes mellitus can cause various complications and eventually leads to death. ${ }^{1,2}$ According to Riskesdas $2013^{3}$, the prevalence of diabetes mellitus in Indonesia was $2.1 \%$, higher than it was in 2007 , which was $1.1 \%$. The International Diabetes Federation (IDF) stated that approximately 5 million people died because of diabetes mellitus in 2015 globally. ${ }^{2}$ One of the most common complications of diabetes mellitus is diabetic foot ulcers (DFU). DFU can cause amputation, which decreases the patient's quality of life and increase the mortality rate. ${ }^{4}$ DFU has been a global health problem due to it can cause a decrease in quality of life in diabetic patients. ${ }^{5,6}$

Low vitamin $D$ serum levels were found in patients with DFU. ${ }^{7}$ Vitamin $D$ is known to be correlated with wound healing and insulin resistance and is useful in predicting DFU. ${ }^{8}$ The effects of vitamin $D$ supplementation are including phagocytosis induction, macrophage activation, insulin receptor expression activation, and cytokines down regulation. ${ }^{9-11}$ Vitamin $D$ is also known to have an ability to affect the pancreatic beta cells and increase insulin sensitivity. ${ }^{12}$ The result evalution of vitamin D serum levels is not routinely done in DFU patients in Indonesia. The correlation between serum levels of vitamin $D$ and DFU degree of severity needs to be studied in order to know the importance of its examination.

\section{METHOD}

This study is an observational study using a cross-sectional design to determine the correlation between the serum level of vitamin $D$ and the severity degree of DFU. The study was conducted in RSCM from May to June 2019. The study subjects were adult DFU patients with a normal ankle-brachial index. The exclusion criteria were patients who had vitamin $\mathrm{D}$ supplementation within the past three months. Thirty DFU patients with normal anklebrachial index were grouped by their degree of severity according to the Wagner classification. The patients' serum level of vitamin $D$ was examined using the chemiluminescent immunoassay method. Univariate and bivariate analyses were done to investigate the correlation between the two variables using SPSS version 20.

\section{RESULTS}

Thirty subjects with DFU and normal anklebrachial index were included in this study. Eighteen subjects were male $(60 \%)$, and 12 subjects were female $(40 \%)$. The average age of the subjects was 57 years old, the Wagner classification grade median 
was 3 with 0 - 5 range, and the average serum level of vitamin D was $10.58 \mathrm{ng} / \mathrm{mL}$ (Table 1 ).

Table 1. Subjects characteristics.

\begin{tabular}{lccccc}
\hline & Mean & SD & Median & Min & Max \\
\hline Age & 57 & 6 & 58 & 46 & 67 \\
Wagner & 3 & 2 & 3 & 0 & 5 \\
$\begin{array}{l}\text { Classification } \\
\text { Vitamin D }\end{array}$ & 10.58 & 4.59 & 9.50 & 4.00 & 18.00 \\
$\begin{array}{l}\text { Serum Level } \\
\text { HbA1C }\end{array}$ & 9 & 2 & 8 & 7 & 14 \\
Leukocyte & 18792 & 6733 & 17225 & 9540 & 29910 \\
\hline
\end{tabular}

The serum level of vitamin $D$ was found to be strongly correlated with the DFU degree of severity, according to the Wagner classification ( $p$ $<0.001, r=-0.901$, figure 1 ).

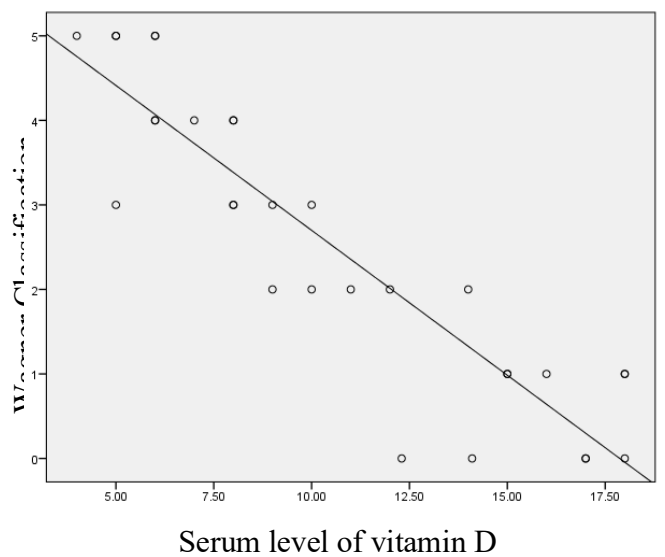

Figure 1. A random diagram depicts the correlation between vitamin $D$ serum levels and DFU severity degree according to Wagner classification. Spearman correlation test was done and resulted in a significant difference ( $p$ value $<0.001$ ) and strong correlation $(r=-0.901)$.

\section{DISCUSSION}

This study included 30 DFU patients with a normal ankle-brachial index. Eighteen patients were male $(60 \%)$, and 12 patients were female (40\%). The subjects' average age was 57 years old, and the average serum level of vitamin D was $10.58 \mathrm{ng} / \mathrm{mL}$.
There was no subject found to have a normal serum level of vitamin $\mathrm{D}$, which is above $30 \mathrm{ng} / \mathrm{mL}$. Therefore all of the study subjects' vitamin D status was deficient.

The correlation between serum level of vitamin D and DFU degree of severity was analyzed and resulted in a negative correlation. The higher the DFU degree of severity, according to the Wagner classification found in the subjects, the lower the serum level of vitamin $D$ found. A study conducted by Dai J, et al. stated that severe vitamin D deficiency was significantly correlated with an increased risk of diabetic foot ulceration. The same study also stated that there was a significant decrease in vitamin $D$ serum levels in patients with DFU. A different study from Zubair et al. stated that a low level of $25(\mathrm{OH}) \mathrm{D}$ had a significant effect on diabetic foot ulcer pathogenesis and was correlated with the severity of the ulcers. Tiwari, et al. stated that $25(\mathrm{OH}) \mathrm{D}$ levels were significantly lower in diabetic patients with infected ulcers.

Sung CC et al. conducted a study in 2012 and stated that the prevalence of hypovitaminosis $D$ was found higher in patients with diabetes mellitus compared to the control group $(p<0.001) .{ }^{12}$ This study revealed that among all 30 study subjects, no subject had a normal serum level of vitamin $D$. Screening of vitamin $D$ is recommended, and supplementation of vitamin $\mathrm{D}$ should be considered in patients with DFU.

\section{CONCLUSION}

The decrease in serum level of vitamin D was correlated with the degree of severity of diabetic foot ulcers. A screening of vitamin $D$ serum levels should be done to patients with diabetic foot ulcers. Supplementations should be given to DFU patients with vitamin $D$ deficiency.

\section{ACKNOWLEDGMENTS}

The author states the original work, and there is no conflict of interest in doing this research.

\section{ORCID ID OF AUTHORS}

\author{
Saleh Harris \\ https://orcid.org/0000-0001-9120-4997
}

Raden Suhartono

https://orcid.org/0000-0002-9142-3062

\section{Aria Kekalih}

https://orcid.org/0000-0001-7811-097X

\section{REFERENCES}

1. Harrison TR, Resnick WR, Wintrobe MM, Thorn GW, Adams RD, Beeson PB, et al. Harrison's principle of internal medicine. Ed 16. New York: McGraw-Hill. 2005

2. Ibrahim A, Jude E, Langton K, De-Jesus FRM, Harkless LB, Gawish H, et al. IDF clinical practice recommendations on the diabetic foot-2017. International Diabetes Federation. 2017

3. Kementrian Kesehatan Republik Indonesia. Profil kesehatan Indonesia tahun 2013. Jakarta: 2014

4. Cronenwett JL dan Johnston KW. Rutherford's vascular surgery. Ed 8. Philadelphia: Elsevier Saunders. 2014

5. Razzaghi R, Pourbagheri H, Momen-Heravi M, Bahmani F, Shadi J, Soleimani Z, et al. The effects of vitamin $D$ supplementation on wound healing and metabolic status in patients with diabetic foot ulcer: A randomized, double-blind, placebo-controlled trial. Journal of Diabetes and Its Complications. 2016

6. Macido A. Diabetic foot ulcers and vitamin D status: A literature review. SAGE Open Nursing. 2018; 4: 1-9 
7. Feldkamp J, Jungheim K, Schott M, Jacobs B, dan Roden M. Severe vitamin D3 deficiency in the majority of patients with diabetic foot ulcers. Horm Metab Res. 2018

8. Yakob MAH, Leong JF dan Pande KC. Vitamin D and other biochemical markers of nutrition in patients with diabetic foot infection in Brunei Darussalam. In IOF Regionals $-5^{\text {th }}$ Asia Pasific Osteoporosis Meeting. Osteo- poros Int. 2014; 25: 639

9. Van Etten E, Decallonne B, Bouillon R and Mathieu C. NOD bone marrow derived dendritic cells are modulated by analogs of 1,25-dihydroxyvitamin D3. The Journal of Steroid Biochemistry and Molecular Biology. 2004; 89(90): 457 - 459

10. Helming L, Bose J, Ehrchen J, Schiebe S, Frahm T and Geffers R. 1 $\alpha, 25$-dihydroxyvitamin D3 is a potent suppressor of interferon $\gamma$-mediated macrophage activation. Blood. 2005; 106: $4351-4358$

11. Pittas AG, Lau J, Hu FB and Dawson-Hughes B. The role of vitamin D and calcium in type diabetes: $A$ systematic review and meta-analysis. The Journal of Clinical Endocrinology and Metabolism. 2007; 92: $2017-2029$

12. Sung CC, Liao MT, Lu KC, Wu CC. Role of vitamin D in insulin resistance. J Biomed Biotechnol. 2012; 2012: 634195 